\title{
Regional Disparity Analysis for Iron Status of School-Going Children from Punjab, India
}

\author{
Sukhdeep Kaur*, Kiran Bains and Harpreet Kaur \\ Department of Food and Nutrition, Punjab Agricultural University, \\ Ludhiana, India (141004) \\ *Corresponding author
}

\section{Keywords}

School Children, Iron Status, Region, Punjab, Anemia

\section{Article Info}

Accepted:

15 January 2019

Available Online:

10 February 2019

\section{A B S T R A C T}

The aims of this study were to assess regional disparity in anemic status and to identify the sociodemographic factors associated with the prevalence of anemia among school-children from Punjab, India. A school-based cross-sectional study was conducted on 210 children (11-17y) randomly selected from government schools of three regions of Punjab, namely Majha $(n=45)$, Doaba $(n=45)$ and Malwa $(n=120)$. Data on sociodemographic characteristics and dietary intake of children were collected through questionnaire based survey. Information on clinical signs/symptoms of anemia and compliance to iron-folic acid supplementation was obtained. Hemoglobin concentration was estimated by cyanmethaemoglobin method. Data were analyzed by Tukey's post-hoc test and Fisher's exact test using SPSS version 23.0. Overall, children's diets were highly inadequate in iron, i.e., less than $43 \%$ of the recommended dietary allowances. Clinical examination showed more than half of the subjects exhibiting signs/symptoms of anemia. Compliance to iron-folic acid supplementation was $100 \%$ in Majha region subjects, while, it was 93 and $77 \%$ in Doaba and Malwa region subjects, respectively. Anemia prevalence was 91, 98 and 100\%, among school-children of Majha, Malwa and Doaba region, respectively. Mean hemoglobin level of the subjects from Majha region $(10.7 \mathrm{~g} / \mathrm{dl})$ was statistically significantly $(\mathrm{p}=0.029)$ higher than Doaba region $(10.4 \mathrm{~g} / \mathrm{dl})$ and non-significantly higher than Malwa region subjects $(10.4 \mathrm{~g} / \mathrm{dl})$; however, the age and gender specific mean hemoglobin values of all the subjects was lower than the reference values for their corresponding age groups. In Majha region, caste $(\mathrm{p}=0.02)$ and family income $(\mathrm{p}=0.01)$ were found significantly associated with anemia. The study finds anemia as a severe public health problem among school-children of Punjab. This paper fulfills an identified need to undertake more studies considering regional variations across the states, in order to obtain a clearer picture on magnitude of the problem, causes and factors associated with anemia.

\section{Introduction}

Globally, Iron Deficiency Anemia (IDA) is the most common micronutrient deficiency disorder, mainly affecting preschool children, pregnant women and lactating mothers (Kotecha, 2011). "Anemia" is used for a group of conditions that result from an inability of erythropoietin tissues to maintain a normal hemoglobin $(\mathrm{Hb})$ concentration on 
an account of inadequate supply of one or more nutrients leading to a reduction in the total circulating hemoglobin. For the formation of and normal growth of RBCs, iron and vitamins, like folic acid and $\mathrm{B}_{12}$ are essential (Srilakshmi, 2005). Lack of circulating $\mathrm{Hb}$ leads to fatigue and diminished capability to perform hard labour; however, they occur out of proportion to the degree of anemia and probably are due to a depletion of proteins that require iron as a part of their structure. Increasing evidence suggests that deficiency or dysfunction of non-hemoglobin proteins has deleterious effects such as muscle dysfunction, pagophagia (pica), dysphagia (difficulty or discomfort in swallowing), poor scholastic performance, altered resistance to infection, and altered behaviour (Harper and Conrad, 2015).

Pallor indicated by yellow discoloration of the skin, mucosa and body secretions, mainly conjunctiva, nail beds and crease of palm, is considered as the most vital clinical sign of anemia. The clinical manifestations of anemia depend on whether anemia is of rapid or insidious onset. Anemia of gradual onset (if mild) may be asymptomatic or simply manifest as fatigue, headache and pallor; whereas if anemia is more severe, present with features such as dyspnoea (difficult breathing), tachycardia, palpitations, angina, light-headedness, faintness, and signs of cardiac failure (Weatherall and Hatton, 2010).

In India, there is the widespread occurrence of IDA; that may be attributed to undesirable cultural practices in the cooking and preparation of foods such as discarding the cooking water from cereals, mainly seen in the rural areas of the country reduces the nutritive value of food (Shekhar and Babu, 2009). About $73 \%$ of the children aged 5-11 years, in India, are suffering from anemia. Based on India State Hunger Index, Punjab has the lowest level of hunger in India
(Menon et al., 2009). As per Planning Commission of India (2011-12), the percentage of below poverty line (BPL) population in Punjab is $8.3 \%$, which is significantly lower than the national average. According to National Sample Survey (NSS)$68^{\text {th }}$ round (2011-12), the average Monthly Per Capita Expenditure (MPCE) of rural Punjab was the second highest among major states after Kerala. Despite the economic progress, Punjab lags behind in social development, particularly in the area of health of children. According to National Family Health Survey (NFHS-3, 2005-06), in Punjab, majority $(66 \%)$ of the children under five years of age were suffering from anemia.

An appropriate diet has a considerable effect on society's health improvement. Eating habits in adolescence often differ substantially from those in any other phase of life. An unbalanced diet in the adolescents could damage their health and quality of life (Barzegari et al., 2011). Anemic children are more likely to be underweight too, because in developing countries like India, poor bioavailability of dietary iron coupled with low intake of heme-iron derived from animal foods is a major etiological factor for anemia. Such higher rates of anemia among children could affect their physical work capacity and cognition; and because of these adverse impacts, studies on the magnitude of anemia among school age children have paramount importance (Assefa et al., 2014).

The geographic location of a child is an important determinant of his/her nutritional status, as the regions with poor nutritional status of the population tend to pull the overall health status of the country down (Bishwakarma, 2011). Many countries maintain a degree of heterogeneity between its states or regions due to different ethnic or religious groups, economic development, geography or climate. All these are reflected 
on socio-economic indicators as well as health indicators (Smith et al., 2005). The analysis of the nutritional status of children in India would be incomplete without paying attention to the health related sociodemographic and regional disparities that exist between and within the states, and the inequalities that persist among different sub-groups of the population. However, only few studies have attempted to quantify the contribution of these factors in child nutrition outcomes. In this regard, the study aimed to assist policy makers and state health ministries, by assessing the regional disparity in anemia and identifying the factors associated with anemia among 210 schoolchildren aged 11-17 years, from Punjab (India).

\section{Materials and Methods}

\section{Study setting and sampling techniques}

Using a multistage sampling technique, total five districts; one each from Majha $(n=45)$ and Doaba $(n=45)$ regions and three districts from Malwa region $(n=120)$ of Punjab were selected targeting school-children. In the next stage of sampling, two blocks from each district were selected. The last stage included selecting two rural and one urban government school from each block selected in order to have a total random sample size of 210 children in the age group of 11-17 years. As Malwa region makes up the majority of Punjab state $(65 \%$ of the total area and $59 \%$ of the total population), it is considered as the biggest region in Punjab (Census of India, 2011). Thus in the study also, the proportion of school-children from Malwa region was more.

Anemic status was defined based on the WHO (2011) criteria for different hemoglobin cut-offs for children aged 11-17 years. Inclusion criteria consisted of healthy children aged 11-17 years, residing in the study area for a minimum period of 6 months; children enrolled in government schools; and who were able to provide verbal or written consent to participate in the study. Exclusion criteria comprised of children with significant medical conditions (e.g., asthma, comorbidities); who were unwilling to provide blood samples; and age outside of study limits were excluded from the study. Ethical clearance for the study was taken from the Institutional Review Board of Punjab Agricultural University, Ludhiana (Punjab, India). Consent of each participant was also ascertained from the parents through the school authorities.

\section{Data collection tools and methods}

A well-structured questionnaire was formulated and pre-tested to ensure the validity of the questionnaire. On the basis of information collected and difficulties faced, necessary modifications were incorporated into the final questionnaire. A survey was conducted using a questionnaire based interview to obtain information on sociodemographic characteristics, dietary iron intake, clinical signs/symptoms of anemia, compliance to WIFS or iron-folic acid supplementation and $\mathrm{Hb}$ concentrations.

\section{Sociodemographic characteristics}

Subjects were divided into different categories according to age (11-12, 13-15, 16$17 \mathrm{y})$; gender (girls and boys); religion (Sikh, Hindu and Others-Muslim, Christian, Jain) and caste (general, scheduled caste/SC, backward class/BC). In India, SCs are considered as the lowest caste and socially excluded group of people, facing discrimination in terms of health services, economies and education (PACS, 2016). Data on parent's occupation (farming, service, labour, self-employment/business and non- 
working), family income ( $\leq$ Rs. 10,000 and above 10,000/month) were collected. Parent's education was categorized into no education, up to matric and above higher secondary. In India, matric or matriculation refers to the final year of tenth class, which ends at $10^{\text {th }}$ Board $\left(10^{\text {th }}\right.$ grade), and the qualification consequently received by passing the national board exams or the state board exams, commonly called "matriculation exams" (IPFS, 2018).

\section{Dietary iron intake}

Data pertaining to iron intake of the subjects was collected by 24-hour recall method for the four meals consumed (i.e., breakfast, lunch, dinner and snacks), in three consecutive days was used (Gibson and Ferguson, 1999). The subjects were provided with different sets of standardized bowls and glasses to record the exact amount of foods and beverages consumed by them. The mean daily iron intake was then assessed using DietCal software (Kaur, 2015) and compared with the recommended dietary allowances (RDA) of Indian Council of Medical Research (ICMR, 2010). The percent adequacy of iron intake was also calculated.

\section{Clinical examination for the signs/symptoms of anemia}

Clinical examination of the subjects was done by a physician. Information on various signs and symptoms of anemia such as paleness of skin or conjunctiva, paleness and smoothness of tongue, flat or spoon shaped nails, lethargy/breathlessness, headache etc., was recorded as prescribed by Jeliffe (1966).

\section{Compliance to weekly iron-folic acid supplementation Program (WIFS)}

In 2012, the government of India has initiated weekly iron folic acid supplementation scheme (WIFS) (100 mg elemental Iron and $500 \mu \mathrm{g}$ folic acid with biannual de-worming), under National Rural Health Mission (NRHM), to address nutritional (iron deficiency) anemia among school going children and adolescents (aged 10-19 years) enrolled in government/government aided/municipal schools in both rural and urban areas (NRHM, 2013). Subject's adherence to WIFS or iron-folic acid supplementation (IFA) for the past 6 months was ascertained.

\section{Hb estimation}

A finger prick blood sample of each subject for $\mathrm{Hb}$ determination were collected by a laboratory technician, using a portable hemoglobinometer instrument (HemoCue). $\mathrm{Hb}$ concentration was estimated by cyanmethaemoglobin method of International Nutritional Anemia Consultative Group (INACG, 1985). The WHO (2011) categories to classify anemia were used. Mild anemia corresponds to $\mathrm{Hb}$ concentration of 11-11.4 $\mathrm{g} / \mathrm{dl}$ for children aged 11y; and 11-11.9 g/dl for children aged $12-14 y$, and also for females aged $15 \mathrm{y}$ and above. For males aged $15 \mathrm{y}$ and above, mild anemia corresponds to $\mathrm{Hb}$ level of 11-12.9 $\mathrm{g} / \mathrm{dl}$. For all the age groups, moderate anemia corresponds to $\mathrm{Hb}$ level of 8-10.9 g/dl, while severe anemia corresponds to level less than $8 \mathrm{~g} / \mathrm{dl}$. The cut-off criterion indicating anemia is the $\mathrm{Hb}$ level of $11.5 \mathrm{~g} / \mathrm{dl}$ for children aged $11 \mathrm{y} ; 12 \mathrm{~g} / \mathrm{dl}$ for children aged 12-14y and females aged $15 \mathrm{y}$ and above; while, for males aged $15 \mathrm{y}$ and above, it is 13 $\mathrm{g} / \mathrm{dl}$.

\section{Statistical analysis}

Data analyses were conducted using SPSS version 23.0 (SPSS Inc., USA). Dichotomous dependent variable was anemia (Yes or No), whereas, independent variables were age, gender, caste, religion, parent's education, 
occupation and family income. Descriptive statistics consisted of simple frequency distributions, percentages and means with standard deviations (SD) of selected variables. To assess significant regional differences in the mean $\mathrm{Hb}$ level and iron intake (continuous variables) of the subjects, Tukey's post-hoc test (ANOVA) was applied. The Shapiro-Wilk test $(\mathrm{p}<0.05)$ and a visual inspection of their histogram, box-plots, and normal Q-Q plots showed that, for all the independent variables, anemia was not normally distributed; and therefore nonparametric test was applied. Bivariate association between dependent and independent variables was tested using Fisher's Exact Test (two-tailed). A $p$-value of $\leq 0.05$ was considered to indicate statistical significance.

\section{Results and Discussion}

\section{Sociodemographic characteristics}

Bivariate association between anemia and sociodemographic characteristics of schoolchildren from Majharegion, is shown in Table 1. Prevalence of anemia according to sociodemographic characteristics of schoolchildren from Doaba and Malwa region, is presented in Table 2 and 3, respectively.

A total of 210 school-children participated in the study, of which, majority were girls. The mean age of school-children was $14.0 \pm 1.8$ years. Most of the children from Majha (89\%) and Malwa region (79\%) were Sikhs, whereas, from Doaba region, Hindus (58\%) predominated. From all the regions, the proportion of SC subjects was more compared to other castes. Doaba region had maximum number of SC subjects ( $82 \%)$, followed by Majha (53\%) and Malwa region (50\%). Among all the Indian states, Punjab, has the highest percentage $(32 \%)$ of SC population (Census of India, 2011). Majority of the children's parents were educated up to matric and very few had above higher secondary education, thus indicating that number of those without any worthwhile schooling was quite substantial. Majha region had the highest and Doaba region had the least proportion of illiterate parents. Labour was the most pursued occupation of the fathers; and mothers were mostly housewives. Regarding family income, it was found that from Majha, Doaba and Malwa region, most (62\%, 80\% and $75 \%$, respectively) of the subjects were from low socio-economic status households earning $\leq$ Rs. 10,000/month.

\section{Dietary iron intake}

Mean daily (mg) and percent adequacy (\%) of iron intake of school-children from three regions of Punjab, is presented in Table 4. Overall, mean iron intake of girls from Majha, Doaba and Malwa region was 11.6 vs. 10.5 vs. $8.8 \mathrm{mg}$, respectively. Majha region girls had significantly higher mean values than Doaba $(\mathrm{p}=0.010)$ and Malwa $(\mathrm{p}=0.000)$ region girls.

On the other hand, the mean daily iron intake (11.1 mg) of Malwa region boys was higher than Majha (10.8 $\mathrm{mg}$ ) and Doaba region (10.0 $\mathrm{mg}$ ) boys; although no significant regional differences $(p=0.286)$ were found. Children's diets were highly inadequate in iron, i.e., less than $43 \%$ of the RDAs of ICMR (2010).

Regional variation in the nutrient intake can cause significant heath disparity, and this variability may be mediated by factors such as food availability, food customs and culture. Interpreting whether the nutrient intake among children are adequate or not, will help support health care providers, nutritionists and food-based companies in developing appropriate strategies and nutrition policies to tackle nutrient deficiencies and disorders and eradicate health disparities. 
Clinical examination for the signs/symptoms of anemia

As shown in Figure 1, from Majha region, majority $(80 \%)$ of the subjects reported of breathlessness, followed by headache $(78 \%)$, lethargy $(76 \%)$, loss of appetite $(73 \%)$, pale conjunctiva (53\%) and pale skin (51\%). From Doaba region, majority (69\%) had lethargy, followed by breathlessness and pale skin (62\% each), headache (60\%), pale conjunctiva (58\%) and loss of appetite (56\%). From Malwa region, about $61 \%$ children had breathlessness, followed by headache and lethargy (52\% each), pale skin $(47 \%)$, pale conjunctiva (45\%) and loss of appetite $(40 \%)$.Hair changes and koilonychias (spoon shaped nails) are evident only when there is severe degree of anemia. Overall, more than half of the subjects from all the regions exhibited one or more clinical signs/symptoms of anemia. However, negligible percentage of them had paleness/smoothness of tongue and spoon shaped nails; while, no hair changes were observed; thus indicating that severe form of anemia may not present among children from Punjab. Consistently, other studies also showed IDA associated signs/symptoms of anemia (Sabale et al., 2013; Gupta et al., 2014; Habib et al., 2016). The presence and degree of anemia and its underlying etiology can be identified clinically by careful physical examination and the appropriate therapy could be administered for evaluation and management of this condition. The clinical signs and symptoms of anemia can therefore assist in diagnosis where facilities for biochemical testing are not available.

\section{Compliance to WIFS program}

In Majha region, compliance to WIFS or ironfolic acid supplementation (IFA) was $100 \%$ in the subjects; whereas in Doaba and Malwa region, it was ensured by 93 and $77 \%$ subjects, respectively. During the research survey, when children were asked about the reasons for not taking supplements, stomach pain, nausea, vomiting, general disliking of tablets due to metallic taste and peer influence were found to be predominant causes for refusal of IFA tablets. Conversely, other studies reported far lower compliance (16$53 \%$ ) to IFA in school-children because of the perception that IFA tablets causes weight gain and adverse side effects, with nausea and vomiting as the most common (Priya et al., 2016; Sajna and Jacob, 2017). Another reason for low consumption of supplements by the children from Malwa region, could be partly attributed to lack of concern among teachers regarding administration of IFA tablets; and partly due to low coverage of WIFS in some government schools of Malwa region, especially those located in remote areas. In this context, a study reported that despite the awareness among teachers, about the ongoing WIFS, only $80 \%$ and $40 \%$ knew the composition of IFA tablet and name of the deworming tablet, respectively; which indicated that compliance to IFA was likely to have been influenced by the teacher's thorough knowledge regarding WIFS program (Sau, 2016). Thus, along with state and district-level planning, implementation and monitoring of micronutrient intervention policies and programs, efforts should be focused on community level programs too, because sometimes status of these intervention programs at the community level do not necessarily reflect those at the state level.

\section{Hb estimation}

Blood $\mathrm{Hb}$ levels of school-children from three regions of Punjab, is given in Table 5. Regional disparity analysis showed that mean $\mathrm{Hb}$ levels of children aged 11y from Majha, Doaba and Malwa region was 10.6, 10.1 and $10.3 \mathrm{~g} / \mathrm{dl}$; of those aged $12-14 \mathrm{y}$, was $10.9,10.1$ 
and $10.2 \mathrm{~g} / \mathrm{dl}$; whereas, mean $\mathrm{Hb}$ values of girls vs. boys aged $15-17 \mathrm{y}$ was 10.0 vs. 11.0 , 10.7 vs. 10.6 and 10.7 vs. $10.8 \mathrm{~g} / \mathrm{dl}$, respectively. No significant regional differences $(\mathrm{p}=0.485)$ were noted in mean $\mathrm{Hb}$ level of girls; whereas, substantial $(\mathrm{p}=0.05)$ disparity was found in mean $\mathrm{Hb}$ level of boys. The mean $\mathrm{Hb}$ level $(11.1 \mathrm{~g} / \mathrm{dl})$ of boys from Majha region was higher than those from Doaba $(10.4 \mathrm{~g} / \mathrm{dl})$ and Malwa region $(10.7 \mathrm{~g} / \mathrm{dl})$. However, a Tukey post-hoc test revealed that statistically significant $(\mathrm{p}=0.05)$ difference was found only between Majha vs. Doaba region boys, but not between Doaba vs. Malwa region boys $(\mathrm{p}=0.550)$, and Majha vs. Malwa region boys $(\mathrm{p}=0.164)$.

Overall, significant $(\mathrm{p}=0.024)$ disparity was observed in mean $\mathrm{Hb}$ levels of the subjects from three regions of Punjab. Furthermore, a Tukey post-hoc test revealed that the mean $\mathrm{Hb}$ level of subjects from Majha region $(10.7 \mathrm{~g} / \mathrm{dl})$ was significantly higher $(\mathrm{p}=0.029)$ compared to Doaba region $(10.4 \mathrm{~g} / \mathrm{dl})$ subjects. Although the mean $\mathrm{Hb}$ level of subjects from Majha region was higher compared to Malwa region subjects $(10.4 \mathrm{~g} / \mathrm{dl})$, the difference was not statistically significant $(\mathrm{p}=0.052)$. For most of the age groups, Majha region subjects had marginally higher mean values as compared to other regions, however, the age and gender specific mean $\mathrm{Hb}$ values of all the subjects was lower than the reference values for their corresponding age groups. Similar results have been reported by Hussain et al (2013); whereas, in contrast, Achouri et al (2015) found much higher mean $\mathrm{Hb}$ values among school-children in Kenitra, Northwest of Morocco.

\section{Prevalence of anemia}

Prevalence of anemia among school-children from three regions of Punjab, on the basis of (WHO, 2011) classification, is depicted in
Table 6. Regional disparity analysis showed that overall, prevalence of anemia among children from Majha, Doaba and Malwa region was 91 vs. 100 vs. $98 \%$, out of which, majority (71 vs. 84 vs. $80 \%$ ) were moderately anemic and 20 vs. 16 vs. $18 \%$ had mild anemia, respectively. There was no case of severe anemia in children. Almost similar prevalence rates have been reported among children from different districts of Punjab such as Amritsar (Majha), Ludhiana, Moga, Faridkot and Patiala (Malwa) (Sidhu et al., 2007; Gupta et al., 2011; Bhatia, 2013; Kaur et al., 2015; Garg and Bhalla, 2016). Contrarily, several studies reported much lower prevalence of anemia among school children from other states of India and worldwide (NFHS-4, 2015-16; Birhanu et al., 2018; Cruz-Gongora et al., 2018; Rakesh et al., 2018; Tezera et al., 2018). Similarly, regional disparities in the prevalence of anemia were observed in China, Brazil, Ghana and in 107 countries worldwide (Luo et al., 2011; Horta et al., 2013; Stevens et al., 2013; USAID, 2014).

According to WHO (2011), anemia is considered as a severe public health problem when the prevalence is greater than $>=40 \%$. Accordingly, above $90 \%$ prevalence of anemia in all the regions confirmed the existence of severe public health problem in the study area.

However, the prevalence of anemia was lower and blood $\mathrm{Hb}$ levels were better among children from Majha region as compared to Doaba and Malwa region. The lowest prevalence in Majha region could be partly explained by the reason that all the subjects were taking iron supplements provided by school authorities; and their mean daily iron intake was also better than subjects from other regions. Similar results have been reported by Bhoite and Iyer (2011) and by Low et al., (2013). 
Table.1 Association between anemia and sociodemographic characteristics, school-children, Majha region

\begin{tabular}{|c|c|c|c|c|}
\hline Variables & $\begin{array}{c}{ }^{\mathrm{a} A n e m i c} \\
\text { n }(\%)\end{array}$ & $\begin{array}{c}\text { Non-anemic } \\
\text { n }(\%)\end{array}$ & $\begin{array}{c}{ }^{\text {b } P} \\
\text { value }\end{array}$ & $\begin{array}{l}\text { Total subjects } \\
\quad(\mathrm{N}=45)\end{array}$ \\
\hline $\begin{array}{l}\text { Age (years) } \\
11-12 \\
13-15 \\
16-17\end{array}$ & $\begin{array}{c}11(92) \\
20(87) \\
10(100)\end{array}$ & $\begin{array}{l}1(8) \\
3(13) \\
0(0)\end{array}$ & 0.79 & $\begin{array}{l}12(27) \\
23(51) \\
10(22)\end{array}$ \\
\hline Gender & $\begin{array}{l}14(88) \\
27(93)\end{array}$ & $\begin{array}{c}2(12) \\
2(7)\end{array}$ & 0.60 & $\begin{array}{l}16(36) \\
29(64)\end{array}$ \\
\hline Religion & $\begin{array}{l}36(90) \\
2(100) \\
3(100)\end{array}$ & $\begin{array}{l}4(10) \\
0(0) \\
0(0)\end{array}$ & 0.99 & $\begin{array}{c}40(89) \\
2(4) \\
3(7)\end{array}$ \\
\hline $\begin{array}{l}\text { General } \\
\text { SC } \\
\text { BC }\end{array}$ & $\begin{array}{c}9(90) \\
24(100) \\
8(73)\end{array}$ & $\begin{array}{l}1(10) \\
0(0) \\
3(27)\end{array}$ & $0.02 *$ & $\begin{array}{l}10(22) \\
24(53) \\
11(25)\end{array}$ \\
\hline $\begin{array}{c}\text { Mother's education } \\
\text { No education } \\
\text { Up to Matric } \\
\text { Above higher secondary }\end{array}$ & $\begin{array}{l}21(88) \\
18(95) \\
2(100)\end{array}$ & $\begin{array}{l}3(12) \\
1(5) \\
0(0)\end{array}$ & 0.68 & $\begin{array}{l}24(53) \\
19(42) \\
2(4)\end{array}$ \\
\hline $\begin{array}{c}\text { Father's education } \\
\text { No education } \\
\text { Up to Matric } \\
\text { Above higher secondary }\end{array}$ & $\begin{array}{l}17(94) \\
19(86) \\
5(100)\end{array}$ & $\begin{array}{c}1(6) \\
3(14) \\
0(0)\end{array}$ & 0.76 & $\begin{array}{l}18(40) \\
22(49) \\
5(11)\end{array}$ \\
\hline $\begin{array}{c}\text { Mother's occupation } \\
\text { Service } \\
\text { Labour } \\
\text { Self-employment/Business } \\
\text { Non-Working } \\
\text { (Housewife/Late) }\end{array}$ & $\begin{array}{l}1(100) \\
9(100) \\
1(100) \\
30(88)\end{array}$ & $\begin{array}{l}0(0) \\
0(0) \\
0(0) \\
4(12)\end{array}$ & 0.64 & $\begin{array}{c}1(2) \\
9(20) \\
1(2) \\
34(76)\end{array}$ \\
\hline $\begin{array}{c}\text { Father's occupation } \\
\text { Farming } \\
\text { Labour } \\
\text { Self-employment/Business } \\
\text { Non-working/Late }\end{array}$ & $\begin{array}{l}7(100) \\
20(95) \\
10(83) \\
4(80)\end{array}$ & $\begin{array}{l}0(0) \\
1(5) \\
2(17) \\
1(20)\end{array}$ & 0.36 & $\begin{array}{l}7(15) \\
21(47) \\
12(27) \\
5(11)\end{array}$ \\
\hline $\begin{array}{c}\text { Family Income }(\mathbf{R s .}) \\
\leq \mathbf{1 0 , 0 0 0} \\
\text { Above } 10,000\end{array}$ & $\begin{array}{c}28(100) \\
13(77)\end{array}$ & $\begin{array}{c}0(0) \\
4(23)\end{array}$ & $0.01 *$ & $\begin{array}{l}28(62) \\
17(38)\end{array}$ \\
\hline
\end{tabular}

${ }^{a}$ Anemia was classified as having $\mathrm{Hb}<\mathrm{WHO}$ (2011) cut-offs for different age groups

${ }^{\mathrm{b}}$ Fisher's exact test (two-tailed)

* Significant at $5 \%$ level 
Table.2 Prevalence of anemia according to sociodemographic characteristics, school-children, Doaba region

\begin{tabular}{|c|c|c|c|}
\hline Variables & $\begin{array}{l}{ }^{a} \text { Anemic } \\
\text { n }(\%)\end{array}$ & $\begin{array}{c}\text { Non-anemic } \\
\text { n }(\%)\end{array}$ & $\begin{array}{l}\text { Total subjects } \\
\quad(\mathrm{N}=45)\end{array}$ \\
\hline Age (years) & $\begin{array}{l}14(100) \\
22(100) \\
9(100)\end{array}$ & $\begin{array}{l}0(0) \\
0(0) \\
0(0)\end{array}$ & $\begin{array}{c}14(31.1) \\
22(48.9) \\
9(20)\end{array}$ \\
\hline Gender & $\begin{array}{l}34(100) \\
11(100)\end{array}$ & $\begin{array}{l}0(0) \\
0(0)\end{array}$ & $\begin{array}{l}34(76) \\
11(24)\end{array}$ \\
\hline Religion & $\begin{array}{l}15(100) \\
26(100) \\
4(100)\end{array}$ & $\begin{array}{l}0(0) \\
0(0) \\
0(0)\end{array}$ & $\begin{array}{c}15(33) \\
26(58) \\
4(9)\end{array}$ \\
\hline $\begin{array}{c}\text { General } \\
\text { SC } \\
\text { BC }\end{array}$ & $\begin{array}{c}3(100) \\
37(100) \\
5(100)\end{array}$ & $\begin{array}{l}0(0) \\
0(0) \\
0(0)\end{array}$ & $\begin{array}{c}3(7) \\
37(82) \\
5(11)\end{array}$ \\
\hline $\begin{array}{c}\text { Mother's education } \\
\text { No education } \\
\text { Up to Matric } \\
\text { Above higher secondary }\end{array}$ & $\begin{array}{c}9(100) \\
31(100) \\
5(100)\end{array}$ & $\begin{array}{l}0(0) \\
0(0) \\
0(0)\end{array}$ & $\begin{array}{c}9(20) \\
31(69) \\
5(11)\end{array}$ \\
\hline $\begin{array}{c}\text { Father's education } \\
\text { No education } \\
\text { Up to Matric } \\
\text { Above higher secondary }\end{array}$ & $\begin{array}{c}6(100) \\
34(100) \\
5(100)\end{array}$ & $\begin{array}{l}0(0) \\
0(0) \\
0(0)\end{array}$ & $\begin{array}{c}6(13) \\
34(76) \\
5(11)\end{array}$ \\
\hline $\begin{array}{c}\text { Mother's occupation } \\
\text { Service } \\
\text { Labour } \\
\text { Self-employment/Business } \\
\text { Non-working (Housewife/Late) }\end{array}$ & $\begin{array}{l}2(100) \\
4(100) \\
1(100) \\
38(100)\end{array}$ & $\begin{array}{l}0(0) \\
0(0) \\
0(0) \\
0(0)\end{array}$ & $\begin{array}{c}2(5) \\
4(9) \\
1(2) \\
38(84)\end{array}$ \\
\hline $\begin{array}{c}\text { Father's occupation } \\
\text { Farming } \\
\text { Service } \\
\text { Labour } \\
\text { Self-employment/Business } \\
\text { Non-working/Late }\end{array}$ & $\begin{array}{l}1(100) \\
5(100) \\
21(100) \\
15(100) \\
3(100)\end{array}$ & $\begin{array}{l}0(0) \\
0(0) \\
0(0) \\
0(0) \\
0(0)\end{array}$ & $\begin{array}{c}1(2) \\
5(11) \\
21(47) \\
15(33) \\
3(7)\end{array}$ \\
\hline $\begin{array}{c}\text { Family income }(\text { Rs. }) \\
\leq \mathbf{1 0 , 0 0 0} \\
\text { Above } 10,000\end{array}$ & $\begin{array}{c}36(100) \\
9(100)\end{array}$ & $\begin{array}{l}0(0) \\
0(0)\end{array}$ & $\begin{array}{c}36(80) \\
9(20)\end{array}$ \\
\hline
\end{tabular}

${ }^{a}$ Anemia was classified as having $\mathrm{Hb}<\mathrm{WHO}$ (2011) cut-offs for different age groups

No measures of association are computed for the cross tabulation of dependent and independent variables because dependent variable (anemia) was a constant 
Table.3 Prevalence of anemia according to sociodemographic characteristics, school-children, Malwa region

\begin{tabular}{|c|c|c|c|}
\hline Variables & $\begin{array}{c}{ }^{a} \text { Anemic } \\
\text { n }(\%)\end{array}$ & $\begin{array}{c}\text { Non-anemic } \\
\text { n }(\%)\end{array}$ & $\begin{array}{l}\text { Total subjects } \\
\quad(\mathrm{N}=\mathbf{1 2 0})\end{array}$ \\
\hline $\begin{array}{ll}\text { Age (years) } \\
\\
11-12 \\
13-15 \\
16-17\end{array}$ & $\begin{array}{l}24(100) \\
63(98) \\
31(97)\end{array}$ & $\begin{array}{l}0(0) \\
1(2) \\
1(3)\end{array}$ & $\begin{array}{l}24(20) \\
64(53.3) \\
32(26.7)\end{array}$ \\
\hline Gender & $\begin{array}{l}31(97) \\
87(99)\end{array}$ & $\begin{array}{l}1(3) \\
1(1)\end{array}$ & $\begin{array}{l}32(27) \\
88(73)\end{array}$ \\
\hline Religion & $\begin{array}{l}94(99) \\
22(96) \\
2(100)\end{array}$ & $\begin{array}{l}1(1) \\
1(4) \\
0(0)\end{array}$ & $\begin{array}{c}95(79) \\
23(19) \\
2(2)\end{array}$ \\
\hline $\begin{array}{l}\text { General } \\
\text { SC } \\
\text { BC }\end{array}$ & $\begin{array}{c}39(98) \\
60(100) \\
19(95)\end{array}$ & $\begin{array}{l}1(2) \\
0(0) \\
1(5)\end{array}$ & $\begin{array}{l}40(33) \\
60(50) \\
20(17)\end{array}$ \\
\hline $\begin{array}{c}\text { Mother's education } \\
\text { No education } \\
\text { Up to Matric } \\
\text { Above higher secondary }\end{array}$ & $\begin{array}{l}43(100) \\
67(98) \\
8(89)\end{array}$ & $\begin{array}{l}0(0) \\
1(2) \\
1(11)\end{array}$ & $\begin{array}{c}43(36) \\
68(57) \\
9(7)\end{array}$ \\
\hline $\begin{array}{l}\text { Father's education } \\
\text { No education } \\
\text { Up to Matric } \\
\text { Above higher secondary }\end{array}$ & $\begin{array}{l}41(100) \\
64(98) \\
13(93)\end{array}$ & $\begin{array}{l}0(0) \\
1(2) \\
1(7)\end{array}$ & $\begin{array}{l}41(34) \\
65(54) \\
14(12)\end{array}$ \\
\hline $\begin{array}{c}\text { Mother's occupation } \\
\text { Service } \\
\text { Labour } \\
\text { Self-employment/Business } \\
\text { Non-Working } \\
\text { (Housewife/Late) }\end{array}$ & $\begin{array}{c}4(100) \\
33(100) \\
5(100) \\
76(97)\end{array}$ & $\begin{array}{l}0(0) \\
0(0) \\
0(0) \\
2(3)\end{array}$ & $\begin{array}{c}4(3.3) \\
33(27.5) \\
5(4.2) \\
78(65)\end{array}$ \\
\hline $\begin{array}{c}\text { Father's occupation } \\
\text { Farming } \\
\text { Service } \\
\text { Labour } \\
\text { Self-employment/Business } \\
\text { Non-working/Late }\end{array}$ & $\begin{array}{l}15(100) \\
7(100) \\
65(98) \\
26(96) \\
5(100)\end{array}$ & $\begin{array}{l}0(0) \\
0(0) \\
1(2) \\
1(4) \\
0(0)\end{array}$ & $\begin{aligned} 15 & (12) \\
7 & (6) \\
66 & (55) \\
27 & (23) \\
5 & (4)\end{aligned}$ \\
\hline $\begin{array}{r}\text { Family Income (Rs.) } \\
\leq 10,000 \\
\text { Above } 10,000\end{array}$ & $\begin{array}{l}89(99) \\
29(97)\end{array}$ & $\begin{array}{l}1(1) \\
1(3)\end{array}$ & $\begin{array}{l}90(75) \\
30(15)\end{array}$ \\
\hline
\end{tabular}

${ }^{\text {a }}$ Anemia was classified as having $\mathrm{Hb}<\mathrm{WHO}$ (2011) cut-offs for different age groups

No measures of association are computed for the cross tabulation of dependent and independent variables because dependent variable (anemia) was a constant 
Table.4 Mean daily (mg) and percent adequacy (\%) of iron intake of school-children from three regions of Punjab

\begin{tabular}{|c|c|c|c|c|c|c|c|c|}
\hline $\begin{array}{c}\text { Iron } \\
\text { Intake }\end{array}$ & $\begin{array}{l}\text { Majha } \\
(n=45)\end{array}$ & $\begin{array}{c}\text { Percent } \\
\text { adequacy }\end{array}$ & $\begin{array}{l}\text { Doaba } \\
(n=45)\end{array}$ & $\begin{array}{c}\text { Percent } \\
\text { adequacy }\end{array}$ & $\begin{array}{l}\text { Malwa } \\
(n=120)\end{array}$ & $\begin{array}{c}\text { Percent } \\
\text { adequacy }\end{array}$ & $\begin{array}{c}\# \\
\text { RDA }\end{array}$ & $\begin{array}{c}{ }^{a} P \\
\text { value }\end{array}$ \\
\hline Girls & & & & & & & & \\
\hline 11-12y & $11.8 \pm 1.1^{\mathrm{a}}$ & 44 & $10.3 \pm 1.3^{\mathrm{b}}$ & 38 & $8.6 \pm 1.4^{\mathrm{c}}$ & 32 & $\begin{array}{l}27 \\
27\end{array}$ & $\stackrel{<}{0001 *}$ \\
\hline $\begin{array}{l}15-15 y \\
16-17 y\end{array}$ & $\begin{array}{l}11.0 \pm 1.3 \\
11.0+1.2^{a}\end{array}$ & $\begin{array}{l}45 \\
42\end{array}$ & $\begin{array}{l}10.1 \pm 1.7 \\
10.5 \pm 1.2^{a}\end{array}$ & $\begin{array}{l}40 \\
40\end{array}$ & $8.5+1.1^{b}$ & $\begin{array}{l}34 \\
33\end{array}$ & $\begin{array}{l}21 \\
26\end{array}$ & $\begin{array}{c}0.001 \\
<\end{array}$ \\
\hline Boys & & & & & & & & $0.001 *$ \\
\hline $11-12 y$ & $10.3 \pm 0.6$ & 49 & $10.4 \pm 0.0$ & 50 & $6.8 \pm 1.1$ & 32 & 21 & $<$ \\
\hline 13-15y & $11.1 \pm$ & 35 & $10.5 \pm 1.5^{\mathrm{a}}$ & 33 & $12.1 \pm 1.5^{b}$ & 38 & 32 & $0.001 *$ \\
\hline $16-17 y$ & $1.1^{\mathrm{ab}}$ & 38 & $8.8 \pm 1.2^{\mathrm{a}}$ & 31 & $12.2 \pm 1.4^{b}$ & 44 & 28 & \\
\hline Overall & $10.7 \pm$ & & & & & & & $0.030^{*}$ \\
\hline Girls & $0.8^{\mathrm{ab}}$ & 43 & $10.5 \pm 1.4^{b}$ & 39 & $8.8 \pm 1.4^{c}$ & 33 & 27 & $0.048 *$ \\
\hline Boys & $\begin{array}{c}11.6 \pm 1.2^{\mathrm{a}} \\
10.8 \pm 0.9\end{array}$ & 40 & $10.0 \pm 1.5$ & 37 & $11.1 \pm 2.5$ & 41 & 27 & $0.002 *$ \\
\hline & & & & & & & & $\begin{array}{c}< \\
0.001^{*} \\
0.286^{\mathrm{NS}}\end{array}$ \\
\hline
\end{tabular}

\# ICMR (2010)

${ }^{\text {a }}$ One-way ANOVA

*Significant at $5 \%$ level

${ }^{\text {NS }}$ Non-Significant

Means with different letter superscripts are significantly different from each other in the row between regions (Tukey's HSD)

${ }^{\$}$ Post hoc tests are not performed because at least one group has fewer than two cases.

Table.5 Blood Hb levels of school children from three regions of Punjab (Mean \pm SD)

\begin{tabular}{|c|c|c|c|c|}
\hline \multirow[b]{2}{*}{ Category } & \multicolumn{3}{|c|}{ Region } & \multirow[b]{2}{*}{$\begin{array}{c}{ }^{a} P \\
\text { value }\end{array}$} \\
\hline & $\begin{array}{l}\text { Majha } \\
(n=45)\end{array}$ & $\begin{array}{l}\text { Doaba } \\
(n=45)\end{array}$ & $\begin{array}{c}\text { Malwa } \\
(n=120)\end{array}$ & \\
\hline Girls & $10.5 \pm 0.7$ & $10.3 \pm 0.5$ & $10.4 \pm 0.5$ & $0.48^{\mathrm{NS}}$ \\
\hline Boys & $11.1 \pm 0.8^{\mathrm{a}}$ & $10.4 \pm 0.6^{b}$ & $10.7 \pm 0.7^{\mathrm{ab}}$ & $0.05^{*}$ \\
\hline Overall & $10.7 \pm 0.8^{\mathrm{a}}$ & $10.4 \pm 0.5^{b}$ & $10.4 \pm 0.6^{\mathrm{ab}}$ & $0.02 *$ \\
\hline
\end{tabular}

${ }^{a}$ One-way ANOVA

* Significant at $5 \%$ level

${ }^{\text {NS Non-Significant }}$

Means with different letter superscripts are significantly different from each other in the row between regions (Tukey's HSD) 
Table.6 Prevalence of anemia among school-children from three regions of Punjab, on the basis of (WHO, 2011) classification

\begin{tabular}{|c|c|c|c|}
\hline $\begin{array}{c}\text { Categories of anemia with } \mathrm{Hb} \\
\text { level ( g/dl ) }\end{array}$ & $\begin{array}{l}\text { Majha } \\
(n=45)\end{array}$ & $\begin{array}{l}\text { Doaba } \\
(n=45)\end{array}$ & $\begin{array}{l}\text { Malwa } \\
(\mathrm{n}=120)\end{array}$ \\
\hline Severe $(\leq 8)$ & - & - & - \\
\hline Moderate (8-10.9) & $32(71)$ & $38(84)$ & $97(80)$ \\
\hline \multicolumn{4}{|l|}{ Mild } \\
\hline $11 y(11-11.4)$ & - & - & $3(2.5)$ \\
\hline $12-14(11-11.9)$ & $5(12)$ & $1(2)$ & $2(1.7)$ \\
\hline $15-17 y$ & & & \\
\hline Female (11-11.9) & - & $5(11)$ & $9(7.6)$ \\
\hline Male (11-12.9) & $4(8)$ & $1(2)$ & $7(6)$ \\
\hline Total mildly anemic subjects & $9(20)$ & $7(16)$ & $21(18)$ \\
\hline Total anemic subjects & $41(91)$ & $45(100)$ & $118(98)$ \\
\hline \multicolumn{4}{|l|}{ Non Anemic } \\
\hline $11 y(\geq 11.5)$ & $1(2)$ & - & - \\
\hline $12-14 y(\geq 12)$ & $3(7)$ & - & - \\
\hline $15-17 y$ & & & \\
\hline Female $(\geq 12)$ & - & - & $1(1)$ \\
\hline Male $(\geq 13)$ & - & - & $1(1)$ \\
\hline Total non-anemic subjects & $4(9)$ & - & $2(2)$ \\
\hline
\end{tabular}

Figures in parentheses represent percentages

Fig.1 Clinical signs/symptoms of anemia among school-children from three regions of Punjab

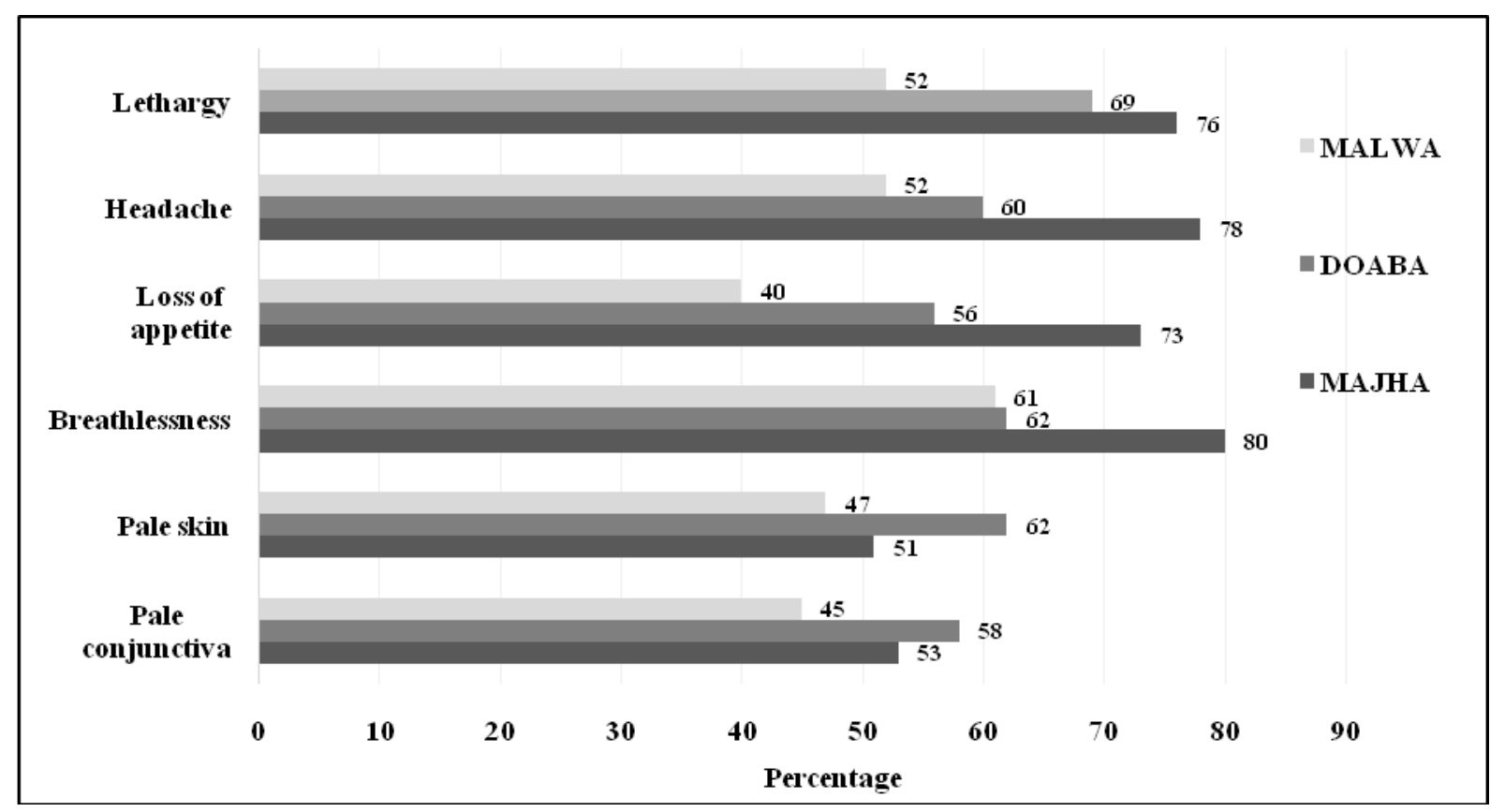


However, the inconsistent effect of IFA supplementation has failed to make any progress in anemia control in Punjab, probably due to poor compliance of the target recipients, and other issues such as occasional unavailability or delayed supply of IFA tablets, poor awareness, and casual program implementation that includes poor coordination between schools and health department. No similar study was found to compare our findings with. Majority of the research studies investigating the prevalence of anemia are mainly based in one city or district of the state. However, the nationwide generalizations about indicators of nutritional status in children can conceal important regional patterns. This study was one of the first to report regional differences in anemic status of school-children from Punjab. More studies should be undertaken considering regional variations across the states, in order to obtain a clearer picture on magnitude of the problem, causes and factors associated with anemia.

\section{Association of anemia with sociodemographic characteristics}

In Doaba and Malwa region, no measures of association were computed for the cross tabulation of dependent and independent variables because anemia was a constant. However, in Majha region, about $91 \%$ of school-children had anemia with no significant association with gender, age, religion, parent's education and occupation; whereas caste $(p=0.02)$ and family income were significantly $(\mathrm{p}=0.01)$ associated with the occurrence of anemia; wherein, compared to other categories, mostly SC children belonging to families earning less than Rs. $10,000 /$ month, were anemic. In agreement, it was shown that children from SC had higher risk of having anemia in India (Goswmai and Das, 2015; Vart et al., 2015). A possible explanation of this could be unhygienic living conditions, poor dietary habits and unawareness regarding benefit schemes for socially-disadvantaged segments of the society. Moreover, families with low household income may not purchase iron-rich foods and expensive non-vegetarian foods. Given the results of the study, it can be concluded that anemia status of the children belonging to low socioeconomic status, in Punjab, might have deteriorated; thus presenting a very distressing situation. It appears that betterment in economic status of such households and timely change in discriminatory attitude towards underprivileged communities are required for bringing about improvements in their health status.

In conclusion, children's diets were grossly inadequate in iron. There was widespread occurrence (over 90\%) of anemia among government school-children from all the regions of Punjab. Although the regional differences were not much profound, to some extent, school-children from Majha region had slightly lower incidence of anemia; their iron intake (dietary/IFA tablet) and $\mathrm{Hb}$ levels were better compared to other regions. Among various sociodemographic factors studied, only caste and family income showed significant association with anemia in Majha region where prevalence rates were substantially higher among SCs and children from low-income families. For Doaba and Malwa regions, anemia was constant irrespective of sociodemographic characteristics. Hence, the policy-makers should give utmost priority to poverty alleviation, more privileges to marginalized communities and better implementation of prevailing health and nutrition programs in the framework of development programs of the state in order to achieve optimum physical, nutritional and health parameters of school- children. 


\section{References}

Achouri, I., Aboussaleh, Y., Sbaibi, R., Ahami, A. and El Hioui, M. 2015. Prevalence of Iron Deficiency Anaemia among School Children in Kenitra, Northwest of Morocco. Pak J Biol Sci. 18(4): 191-195.

Assefa, S., Mossie, A. and Hamza, L. 2014. Prevalence and severity of anemia among school children in Jimma Town, Southwest Ethiopia. BMC Hematol.14, 3.

Barzegari, A., Ebrahimi, M., Azizi, M. and Ranjba, K. 2011. A Study of Nutrition Knowledge, Attitudes and Food Habits of College Students. WASJ. 15(7): 1012-1017.

Bhatia, M. 2013. Hunger and Under-nutrition in Green Revolutionary State of Punjab. IJAFST. 4(4): 359-370.

Bhoite, R. and Iyer, U. 2011. Magnitude of Malnutrition and Iron Deficiency Anemia among Rural School Children: An Appraisal. Asian J. Exp. Biol. Sci. 2(2): 354-361.

Birhanu, M., Gedefaw, L. and Asres, Y. 2017. Anemia among School-Age Children: Magnitude, Severity and Associated Factors in Pawe Town, BenishangulGumuz Region, Northwest Ethiopia. Ethiop J Health Sci. 28(3):259-266.

Bishwakarma, R. 2011). Spatial Inequality in Child Nutrition in Nepal: Implications of Regional Context and Individual/Household Composition. Dissertation, Faculty of The Graduate School, University of Maryland.

Census of India. 2011. Ministry of Home Affairs, The Registrar General \& Census Commissioner. New Delhi, Government of India.

Cruz-Gongora, V.D., Villalpando, S. and Shamah-Levy, T. 2018. Prevalence of anemia and consumption of iron-rich food groups in Mexican children and adolescents: Ensanut MC 2016. Salud Publica Mex. 60, 291-300.

Garg, N. and Bhalla, M. 2016. To study the prevalence of anaemia among school going children in rural area of Faridkot district, India. IJCP. 3(1): 218-223.

Gibson, R.S. and Ferguson, E.L. 1999. An interactive 24-hour recall for assessing the adequacy of iron and zinc intakes in developing countries. HarvestPlus Technical Monograph 8, International Food Policy Research Institute (IFPRI), Washington, DC.

Gupta, A., Sharma, D., Thakur, D., Thakur, A. and Mazta, S.R. 2014. Prevalence and predictors of the dual burden of malnutrition among adolescents in North India. Saudi J Obes. 2(2):63-67.

Gupta, V.K., Maria, A.K., Kumar, A., Bahia, J.S., Arora, S., Singh, R., Shelza, and Gupta, V. 2011. To Study the Prevalence of Anaemia in Young Males and Females with Respect to the Age, Body Mass Index (BMI), Activity Profile and the Socioeconomic Status in Rural Punjab. J Clin Diagn Res. 5(5): 10201026.

Habib, M.A., Black, K., Soofi, S.B., Hussain, I., Bhatti, Z., Bhutta, Z.A. and RaynesGreenow, C. 2016. Prevalence and Predictors of Iron Deficiency Anemia in Children under Five Years of Age in Pakistan, A Secondary Analysis of National Nutrition Survey Data 20112012. PLoS One. 11, e0155051.

Harper, J.L. and Conrad, M.E. 2015. Iron Deficiency Anemia Clinical Presentation. http://emedicine.medscape.com/article/2 02333-clinical.

Horta, B.L., Santos, R.V., Welch, J.R., Cardoso, A.M., Santos, J.V., Assis, A.M.O., Lira, P.C.I. and Coimbra, C.E.A. 2013. Nutritional status of indigenous children: findings from the First National Survey of the Health and 
Nutrition of Indigenous Peoples in Brazil. Int J Equity Health. 12, 23.

Hussain, D., Arefin, M., Hussain, B. and Sarker, A. 2013. Prevalence of Iron Deficiency Anemia and its Biochemical Parameters among the Selected Schoolgoing Under-Privileged Children in Dhaka. Bangladesh J. Vet. Med. 14(2): 130-134.

ICMR. 2010. Nutrient requirements and Recommended Dietary Allowances for Indians. National Institute of Nutrition, Indian Council of Medical Research, Hyderabad, India.

INACG. 1985. International Nutritional Anemia Consultative Group. Measurements of iron status. Nutrition Foundation. New York, NY, pp. 78.

IPFS. 2018. Matriculation in India. https://ipfs.io/ipfs/QmXoypizjW3WknFi JnKLwHCnL72vedxjQkDDP1mXWo6u co/wiki/Matriculation_in_India.html.

Jellife, D.B. 1966. The Assessment of Nutritional Status of the Community. WHO Monograph Series No. 53, Geneva, pp. 50-84.

Kaur, G. 2015. DietCal: A tool for Dietary Assessment \& Planning. Profound Tech Solutions. Department of Dietetics, AIIMS, New Delhi, India.

Kaur, K., Grover, K. and Kaur, N. 2015. Assessment of Nutrition Knowledge of Rural Mothers and Its Effectiveness in Improving Nutritional Status of Their Children. IRJEE. 15(4): 90-98.

Kotecha, P.V. 2011. Nutritional Anemia in Young Children with Focus on Asia and India. Indian J. Community Med. 36(1): 8-16.

Low, M., Farrell, A., Biggs, B.A. and Pasricha, S.R. 2013. Effects of daily iron supplementation in primary-school-aged children: systematic review and metaanalysis of randomized controlled trials. CMAJ. 185, E791-802.

Luo, R., Zhang, L., Liu, C., Zhao, Q., Shi, Y.,
Miller, G., Elaine, Y., Brian, S., Alexis, M., Scott, R. and Reynaldo, M. 2011. Anemia in Rural China's Elementary Schools: Prevalence and Correlates in Ningxia and Qinghai's Poor Counties. J Health Popul Nutr. 29, 471-485.

Menon, P., Deolalikar, and Bhaskar, A. 2009. India State Hunger Index-Comparisons of Hunger Across States. IFPRI.

NFHS-3. 2005-06. National Family Health Survey. International Institute for Population Sciences (IIPS) \& ORC MACRO (2007),India, Mumbai, IIPS.

NFHS-4. 2015-16. National Family Health Survey. International Institute for Population Sciences (IIPS) \& ORC MACRO (2015), India, Mumbai, IIPS.

NRHM. 2013. Ministry of Health and Family Welfare, GOI, Weekly Iron and Folic Acid Supplementation Scheme. http://nhm.gov.in/nrhmcomponnets/repr oductive-child-health/adolescenthealth/wifs.html (accessed 1 July 2018).

NSS-68 ${ }^{\text {th }}$ Round. 2011-12. Household Consumer Expenditure, NSS $68^{\text {th }}$ Round Sch1.0 Type 2: July 2011 - June 2012. Ministry of Statistics \& Programme Implementation, Government of India.

PACS. 2016. Socially Excluded Group Scheduled

Castes. http://www.pacsindia.org/socially_exclu ded_group/aboutpacs/who-we-workwith/socially-excludedgroups/scheduled-castes.

Planning Commission of India. 2011-12. Report of the Expert Group to Review the Methodology for Estimation of Poverty (2009). Planning Commission; PRS.

Priya, H.S., Datta, S.S., Bahurupi, Y.A., Narayan, K.A., Anbarasan, N. and Ramya, M.R. 2016. Factors Influencing Weekly IFA Supplementation Programme (WIFS) among School Children: Where to Focus Our Attention. IJCMR. 3, 1075-1079. 
Rakesh, P.S., George, L.S., Joy, T.M., George, S., Renjini, B.A. and Beena, K.V. 2018. Anemia Among School Children in Ernakulam District, Kerala, India. Indian J Hematol Blood Transfus. https://doi.org/10.1007/s12288-0181001-6.

Sabale, R.V., Kowli, S.S. and Chowdary, P.H. 2013. Prevalence of anemia and its determinants in urban school-going children of Mumbai. Int J Med. Public Health. 3, 325-329.

Sajna, M.V. and Jacob, S.A. 2017. Adherence to weekly iron and folic acid supplementation among the school students of Thrissur corporation - a cross sectional study. Int J Community Med Public Health. 4,1689-1694.

Sau, A. 2016. A Study on Weekly Iron and Folic Acid Supplementation (WIFS) Programme in a School at Rural Area of West Bengal, India. JDMS. 15(6): 4750 .

Shekhar, B.R.C. and Babu, R.P. 2009. Cultural factors in Health and Oral health. Indian J. Dent. Adv.1 (1): 24-30.

Sidhu, S., Kumari, K. and Uppal, M. 2007. Prevalence of Anaemia in Bazigar (Exnomadic Tribe) Preschool Children of Punjab. J Hum Ecol. 21(4): 265-267.

Smith, L.C., Ruel, M.T. and Ndiaye, A. 2005. Why is child malnutrition lower in urban than in rural areas? Evidence from 36 developing countries. World Development. 33(8): 1285-1305.

Srilakshmi, B. 2005. Dietetics: Nutritional Anaemia. New Age International (P) Limited, Publishers, $5^{\text {th }}$ ed., New Delhi.Pp. 126-136.

Stevens, G.A., Finucane, M.M., De-Regil,
L.M., Paciorek, C.J., Flaxman, S.R., Branca, F., Pena-Rosas, J.P., Bhutta, Z.A. and Ezzati, M. 2013. Global, regional, and national trends in haemoglobin concentration and prevalence of total and severe anaemia in children and pregnant and nonpregnant women for 1995-2011: a systematic analysis of populationrepresentative data. Lancet Glob Health. 1, e16-e25.

Tezera, R., Sahile, Z., Yilma, D., Misganaw, E. and Mulu, E. 2018. Prevalence of anemia among school-age children in Ethiopia: a systematic review and metaanalysis. Sys. Rev. 7, 80.

USAID. 2014. Ghana: Nutrition Profile. https://www.usaid.gov/sites/ default/files/documents/1864/USAIDGhana_NCP.pdf 2014.

Vart, P., Jaglan, A. and Shafique, K. 2015. Caste-based social inequalities and childhood anemia in India: results from the National Family Health Survey (NFHS) 2005-2006. BMC Pub Health. 15,537 .

Weatherall, D.J and Hatton, C. 2010. Anaemia: pathophysiology, classification, and clinical features. In: Warrell, D.A., Cox, T.M. and Firth, J.D. (Eds), Oxford Textbook of Medicine, $5^{\text {th }}$ ed., Oxford University Press, Oxford.

WHO. 2011. Iron Deficiency Anaemia: Assessment, Prevention and Control, a Guide for Programme Managers. Geneva. http://www.who.int/nutrition/ publications/micronutrients/anaemia_iro n_deficiency/WHO_NHD_01.3/en/index .html.

\section{How to cite this article:}

Sukhdeep Kaur, Kiran Bains and Harpreet Kaur. 2019. Regional Disparity Analysis for Iron Status of School-Going Children from Punjab, India. Int.J.Curr.Microbiol.App.Sci. 8(02): 2008-2023. doi: https://doi.org/10.20546/ijcmas.2019.802.235 